\title{
Contributions of recycled wastewater to clean water and sanitation Sustainable Development Goals
}

\author{
Cecilia Tortajada ${ }^{1 凶}$
}

Water resources are essential for every development activity, not only in terms of available quantity but also in terms of quality. Population growth and urbanisation are increasing the number of users and uses of water, making water resources scarcer and more polluted. Changes in rainfall patterns threaten to worsen these effects in many areas. Water scarcity, due to physical lack or pollution, has become one of the most pressing issues globally, a matter of human, economic and environmental insecurity. Wastewater, whose value had not been appreciated until recently, is increasingly recognised as a potential 'new' source of clean water for potable and non-potable uses, resulting in social, environmental and economic benefits. This paper discusses the potential of recycled wastewater (also known as reused water) to become a significant source of safe water for drinking purposes and improved sanitation in support of the Sustainable Development Goals.

npj Clean Water (2020)3:22; https://doi.org/10.1038/s41545-020-0069-3

\section{INTRODUCTION}

The Sustainable Development Goals (SDGs) are the most recent attempt by the international community to mobilise government, private and non-governmental actors at national, regional and local levels to improve the quality of life of billions of people in the developed and developing worlds. The goals are an ambitious, challenging and much-needed action plan for "people, planet and prosperity" until the year $2030^{1}$.

Of the 17 SDGs, the sixth goal is to "ensure availability and sustainable management of water and sanitation for all". The achievement of this goal, even if partially, would greatly benefit humankind, given the importance of clean water for overall socioeconomic development and quality of life, including health and environmental protection.

In 2000, the Millennium Development Goals (MDGs) aimed at reducing by half the proportion of the population without sustainable access to safe drinking water and sanitation by 2015. This objective, however, did not take into consideration water quality or wastewater management aspects, which represented a main limitation for its achievement ${ }^{2}$. This omission has been rectified in the Sustainable Development Goals (SDGs), where one of the goals (SDG 6) calls for clean water and sanitation for all people by ensuring "availability and sustainable management of water and sanitation for all". Among other aspects, it considers improvement of water quality by reducing by half the amount of wastewater that is not treated, and increasing recycling and safe reuse globally. This will result in the availability of more clean water for all uses, and on an enormous progress on sanitation and wastewater management. This target unequivocally indicates the close interrelation between clean water, sanitation and wastewater management, giving these two last aspects the importance they deserve. No government of any human settlement irrespective of its size, be it a megacity, mid-size city or large or small town, can provide clean water without concurrently considering sanitation and wastewater management. Clean water is not, and will never be possible, if wastewater is not collected, treated and disposed properly for the intended uses.
Constraints for the provision of clean water and sanitation for all are complex, and depend on decisions of actors at all levels of government, private sector, non-governmental organisations and the public. They are also determined by broad development policies that may or may not prioritise provision of these services over the long-term, national and local action plans that, even when properly formulated, are often not adequately implemented due to short-term planning, lack of managerial, financial and/or man-power capacity and water needs of other sectors such as the energy or agriculture sectors on which the water sector has limited say or control. The most damaging limitation is often political will that is not sustained and that depends on political interests and electoral cycles. These aspects as well as many others that hampered the progress of the MDGs and represent serious constraints for the SDGs include discrepancy between global goals and national and local limitations, lack of continuity in decisions, policies and investments from one administration to the other, poor or inexistent data that inform decision-making or disadvantaged populations that do not have access to appropriate water and sanitation services ${ }^{3}$.

In most developing countries, provision of clean water and, to a certain degree, also sanitation services, are prioritised over other services. Nevertheless, this prioritisation is not always accompanied by sustained support, resources, or interest. Regarding wastewater management, this is simply left behind. There does not seem to be appreciation of the numerous negative impacts wastewater and related pollution have for provision of clean water, and how much they adversely affect human health and the environment.

It is a fact that water resources globally are under pressure from economic development, population growth, urbanisation, and more recently, climate variability and change; however, it is also pollution to a large extent what is restricting the availability of water for all people for all uses in quantity and quality. It is difficult to find a solution because, as discussed earlier, this depends on numerous technical and non-technical decisions that are taken without analysing their implications on water availability. The situations are further exacerbated by legal and regulatory

\footnotetext{
${ }^{1}$ Institute of Water Policy, Lee Kuan Yew School of Public Policy, National University of Singapore, Singapore, Singapore. ${ }^{\circledR}$ email: cecilia.tortajada@nus.edu.sg
} 
frameworks that are not implementable, absence of long-term planning, inadequate management and governance, government capability, neglect of demand-side practices (pricing and nonpricing measures), disregard of awareness building including attitudes and behaviour, and poor intersectoral collaboration. Adequate consideration of these aspects depends on economic, social, environmental, cultural and political contexts and institutional capabilities of the places where they are implemented. Properly pursuing SDGs in general, and SDG 6 in particular, have the potential to improve not only access to water and sanitation and quality of life of billions of people, but also contributing towards better capacities of national and local governments.

SDGs main targets of reducing by half the amount of wastewater that is not treated, and increasing recycling and safe reuse present the distinct possibility of producing 'new' sources of clean water for all uses that would not be available otherwise. It would further mean that wastewater discharged to water bodies would be cleaner and safer than what it is at present, and that source water for communities downstream would be of much better quality. It would further contribute to improvements in aquatic environments.

Potable water reuse is not new. However, what has made it more relevant at local and also at national levels such as in Singapore, and now potentially in United States, is growing water scarcity and pollution that is reducing water resources available for larger populations and more uses.

The rest of the paper presents the poor status of water quality globally, and discusses the distinct potential wastewater treatment and reuse have to produce new sources of clean water, as well as to improve sanitation and wastewater management, supporting the UN's development goal of clean water and sanitation for all. This would also contribute, at least partially, to the progress of several others non-water related SDGs such as poverty alleviation, good health and well-being, and improved education and gender equality. Examples of projects that produce reused water for potable purposes are presented including their benefits, as well as the views of the local populations. Finally, challenges to implement potable water reuse more extensively are discussed.

\section{RESULTS AND DISCUSSION}

Water pollution and impacts on human health and environment Worsening water pollution affects both developed and developing countries. In developing countries, it is mostly due to rapid population growth and urbanisation, increased industrial and other economic activities, and intensification and expansion of agriculture, coupled with lack of local and national legal and institutional capacities (managerial, technical, financial, enforcement, etc.) and political and public apathy to improve and maintain water and wastewater management processes in the long-term. Much attention is given to sanitation, specially to construction of toilets and wastewater treatment plants, but their construction alone will not improve water quality over mediumand long-terms unless commensurate attention is given to significantly improving institutional capacity for planning, management, and implementation ${ }^{4}$.

Water pollution has increased significantly in most rivers in Africa, Asia and Latin America since 1990. Pathogenic and organic pollution has worsened in more than half of river stretches, severely limiting their use. These findings are based on measurements of parameters that indicate pathogen pollution (faecal coliform bacteria), organic pollution (biochemical oxygen demand), and salinity (total dissolved solids $)^{5}$. Although sanitation coverage and wastewater treatment have improved in some countries, they have not been enough to reduce the faecal coliform pollution reaching surface waters ${ }^{6}$. This does not include contamination due to industrial and agricultural wastewater which discharges contain hazardous chemicals, heavy metals, and other inorganic pollutants. Consequently, an estimated 2 billion people use drinking water sources that are contaminated, making millions sick.

According to the Global Burden of Disease studies ${ }^{7}$, between 1990 and 2017, the worst deterioration of water quality was in Southeast Asia, East Asia, and Oceania (86\% increase in the parameters measured), North Africa and the Middle East (58\% increase), and South Asia (56\% increase). Parameters used to estimate unsafe water sources include proportion of individuals globally with access to different water sources (unimproved, improved except for piped supply, or piped water supply), and who have reported use of household water treatment methods such as boiling, filtering, chlorinating or solar filtering (or none of these). For unsafe sanitation, the parameters used are the proportion of individuals with access to different sanitation facilities (unimproved, improved except sewer, or sewer connection).

In developed countries, people's access to safe sources of water and to sanitation and wastewater services has improved. However, these services still lag behind for people in poor urban, peri-urban, and rural areas, showing inequality among and within communities and regions, with the poorest people generally being in the most difficult situations ${ }^{8}$. Water quality has also improved in general, but pollutants have multiplied and diversified, putting pressure on governments and utilities to improve treatment processes for both drinking water and wastewater?.

United States, for example, acknowledges new and longstanding problems. These include a combination of point sources of pollution (such as toxic substances discharged from factories or wastewater treatment plants) and non-point sources (such as runoff from city streets and agricultural sources like farms and ranches). Another problem has been insufficient financial support for municipal wastewater treatment plants ${ }^{10}$. In 2009, according to data reported by the EPA (2009) ${ }^{11}$ and the states, $44 \%$ of river and stream miles assessed, and $64 \%$ of lake acres assessed, did not meet applicable water quality standards and were not apt for one or more intended uses. In 2019, an assessment of lakes at the national level found that $\sim 20 \%$ of them had high levels of phosphorus and nitrogen ${ }^{12}$. Although more work is necessary, the United States has the advantage of robust legal and institutional frameworks that have fostered progress in improving quality in drinking water and bodies of water.

Europe is not without problems. According to the European Environment Agency ${ }^{13}$, good chemical status has been achieved for only $38 \%$ of surface waters and $74 \%$ of groundwater in the EU member states. Surface water bodies are affected mostly by hydromorphological pressures $(40 \%)$, non-point sources of pollution (38\%, mostly agricultural), atmospheric deposition (38\%, mainly mercury), point sources of pollution (18\%) and water abstraction (7\%). In England, only 14\% of rivers meet the minimum good status standard; France, Germany, and Greece have been fined by the European Court of Justice for violating regulatory limits on nitrates, with almost a third of monitoring stations in Germany showing levels of nitrates exceeding EU limits.

Risks posed by emerging contaminants such as pharmaceuticals and microplastics are still poorly understood, and thus cannot be adequately incorporated in planning and management of potable water supply. Current and future research on emerging contaminants and their impacts is necessary to fully understand the best management and treatment processes.

Safe reuse for additional sources of safe water

Safe reuse of water resources (using them more than once) is a radical contribution to the old paradigm of water resources management, which seldom considered the value of recycled 
wastewater and its reuse for potable uses. Larger populations that require more water and produce more wastewater that is not always treated properly, current and projected water scarcity and degradation and water-related health and environmental concerns have led a growing number of cities to treat municipal wastewater to higher quality, and either reusing it for potable and non-potable purposes or discharging it (now cleaner) to the environment. Appropriate regulations, improved technology, more reliable monitoring and control systems, and considerations of public views have made it a feasible alternative to increase the amount of clean water available for potable purposes ${ }^{14}$.

Augmentation of water resources for potable purposes with reused water can be done either directly or indirectly. Terminology varies, but generally, in indirect potable reuse (IPR), reused water is introduced into an environmental buffer (reservoir, river, lake or aquifer) and then treated again as part of the standard supply process. In direct potable reuse (DPR), reused water is sent to a drinking water treatment plant for direct distribution without going through an environmental buffer.

Potable water reuse projects have been implemented in cities in the United States, Namibia, Australia, Belgium, United Kingdom and South Africa, as well as in Singapore ${ }^{15}$. The common denomination in all cases for project development has been water scarcity. All projects have prioritised public health and the environment and risk management. Because water reuse diversifies the water resources available, its value has become more evident during droughts, when surface and groundwater are more limited for all uses.

\section{Local experiences considered successful}

This section refers to potable water reuse in several cities, with emphasis on United States because of its current progress in this area.

United States has developed the largest number of water reuse projects of any country, supported by policies and regulations that promote safe reuse of water from recycled wastewater (in 2017, 14 states had policies to address indirect potable reuse and three to address direct potable reuse, compared with eight and none, respectively, in 2012). Measures have been taken to improve use and management of freshwater resources, developing water management tools and drought preparedness plans, conservation actions, addressing dependence on expensive inter-basin water transfers, assessing climate change, and revising water reuse from the knowledge, management, technological, financial, and publicopinion viewpoints.

In US, there are no specific federal regulations for potable water reuse; however, all potable water should meet federal and state water quality regulations, such as the Safe Drinking Water Act and the Clean Water Act. In parallel to these Acts, several states have developed their own regulations or guidelines governing indirect potable reuse, while direct potable reuse facilities are currently considered on a case-by-case basis. In Big Spring and Wichita Falls, Texas, direct potable reuse has been implemented as the most effective, or the only feasible way to provide clean water ${ }^{16}$.

California is the most progressive state regarding indirect potable water reuse, with the most developed regulatory frameworks. For more than 50 years, several cities have implemented planned replenishment of groundwater basins with reused water. Regulations were adopted in 1978 and revised in 2014. In 2018, indirect potable reuse regulations of surface water augmentation were adopted. They allow reused water to be added to surface water reservoirs that are used as sources of drinking water ${ }^{17}$. No project has been implemented yet but the first two (in San Diego County) are expected to be completed by 2022 .

The state does not have regulations for direct potable reuse at present. However, the State Water Board is working on a Proposed Framework for Regulating Direct Potable Reuse to develop uniform water recycling criteria that will protect public health, and avoid "discontinuities" in the risk assessment/risk management approach as progressively more difficult conditions are addressed $^{18}$.

The best-known potable reuse project in California, in the country, and internationally, is the Orange Country Groundwater Replenishment System. Indirect potable reuse has been the longterm response of the district (as has been for the state) to provide clean water for growing human and environmental needs. The system supplies potable reused water for $\sim 850,000$ people. Reused water is for recharging the groundwater basin to protect it from seawater intrusion. A final expansion project will increase the system's treatment capacity, enabling the district to continue protecting the groundwater basin and providing clean water to its growing population ${ }^{19}$. The project is considered a precursor and benchmark for subsequent water reuse projects in El Paso, Texas, the West Basin Water Recycling Plant in California and the Scottsdale Water Campus in Arizona.

A recent initiative of the EPA, the National Water Reuse Action Plan, has the potential to implement water reuse at the national level. This Action Plan, announced in February 2020, has the objective to secure the country's water future for all uses by improving security, sustainability, and resilience of water resources through water reuse and identify types of collaboration between governmental and nongovernmental organisations to make this possible. The plan also aims to address policy, programmatic issues, and science and technology gaps to better inform related regulations and policies ${ }^{20}$.

Reused water has also been produced in Windhoek and Singapore. Windhoek is the first example of direct potable reuse globally from 1968, as the best, and only alternative to water scarcity, exacerbated by recurrent droughts ${ }^{21}$. Given its importance for water security, potable reuse has been considered for decades as a strategic component of water resources management. During the very severe drought in 2015-2017, surface water (the main water source) fell to $2 \%$ of supply from the normal $75 \%$, putting enormous pressure on the water system and on the domestic, commercial and industrial sectors. Most of the water used to replace the surface water was drawn from the local aquifer, and potable reused water increased to $30 \%$ of supply ${ }^{22}$. Potable water reuse additional domestic supplies and domestic water rationing was not necessary. From October 2019 and through the writing of this article in early 2020, Windhoek faced another very severe drought during which potable water reuse also represented an essential source of clean water for potable purposes, until it finally rained.

In Singapore, production of NEWater (as reused water is known) started in 2003 as part of a long-term strategy to diversify water resources and reduce Singapore's dependence on water imported from Johor, Malaysia, with a goal of resilience and self-sufficiency by 2060 . Reused water meets $\sim 40 \%$ of Singapore's daily water needs and will cover $\sim 55 \%$ by 2060 . During dry months, NEWater is added to the reservoirs to blend with raw water before undergoing treatment and being supplied for potable use ${ }^{23}$. While water reuse was not a new concept in 2003, what has been significant in this case is its large-scale implementation and the wide public acceptance of indirect potable and direct non-potable reuse due comprehensive education and communication strategies $^{24}$. These emphasise the water-scarcity reality in the city-state and the importance of water reuse to produce the water that is needed for overall development.

In Europe, the EU recognises the importance of reducing pressures on the water environment due to water scarcity, and encourages efficient resource use. Its policy on water reuse does not include potable uses, leaving this decision to the member states; it refers only to non-potable uses, with focus on irrigation for agriculture ${ }^{25}$. 
Table 1. Overview of selected planned indirect and direct potable reuse projects, adapted from ref. ${ }^{28}$.

\begin{tabular}{|c|c|c|}
\hline Wulpen, Belgium & 1.9 & $\begin{array}{l}\text { Treated water is injected into the aquifer before being reused } \\
\text { indirectly as a potable water source. }\end{array}$ \\
\hline Essex, UK & 10.5 & Treated water is returned upstream to a river for indirect potable reuse. \\
\hline $\begin{array}{l}\text { Orange County, } \\
\text { California, USA }\end{array}$ & 100 & $\begin{array}{l}\text { Treated water is injected into the aquifer before being reused indirectly } \\
\text { as a potable water source. Capacity is to be increased to } 130 \mathrm{MGD} \text {. }\end{array}$ \\
\hline
\end{tabular}

Within this framework, the only two projects that have been developed in the region so far are the Langford Recycling Scheme in United Kingdom and Torrelle plant in Belgium. Both produce water to be used indirectly for drinking water supplies. The Langford Recycling Scheme operates only when the flow of the River Chelmer is low, supplying up to $70 \%$ of the flow during drought periods. The highest production has been during drought periods in 2005-2006 and 2010-2011 ${ }^{26}$. In Belgium, Torrelle plant supplies safe drinking water to nearby communities, 60,000 people in 2012, and is also used for artificial recharge of the dune aquifer of Saint-André preventing seawater intrusion ${ }^{27}$.

Table 1 presents an overview of the projects mentioned above ${ }^{28}$. In the decades over which these projects have supplied drinking water, no negative health effects have been documented.

\section{Local experiences where challenges remain}

The most recent potable reuse projects that have been stopped are in Australia. The country has robust legal and regulatory frameworks to support potable reuse ${ }^{29}$, but so far only one project has been successfully implemented, in Perth, Western Australia ${ }^{30}$. Two potable water reuse projects in Queensland have been halted due to health concerns, poor communication and public opposition in one case (Toowoomba ${ }^{31}$ ), and on lack of political support in the other case (Western Corridor Recycled Water Project $)^{32}$. In both cases, decisions were taken even when there were concerns on the impacts of climate change in the region and the possibility that rainfall patterns might not be appropriate for future purposes.

Acceptance of potable water reuse requires robust regulations and advanced technology; however, it also requires serious consideration of the soft-aspects such as education, communication and engagement of politicians, decision-makers and the public, and emotional response and trust ${ }^{33}$. Messages should not be limited to the benefits of the projects. They should also discuss aspects such as water quality and safety, water supply alternatives and their feasibility and costs, risk management, and implications for those who will consume the water ${ }^{34}$.

In the developing world, cities in Brazil, Mexico, Kuwait, and India have constructed or are planning projects, for potable water reuse. Their possibilities to succeed are limited as projects would have to be implemented within regulatory, institutional, governance, management, financial and technological frameworks that are robust and promote innovation, and utilities would have to ensure technical, managerial and financial capacities in the longterm. A serious limitation is that water management in general, and collection and conventional treatment of municipal and industrial wastewater in particular, are still challenging; often water quality standards and monitoring are poorly enforced, and risk assessment frameworks are lacking. Irrespective of how important potable water reuse is for clean water and sanitation goals at local, regional and national levels, challenges remain for its extended implementation.
Knowledge gaps and research needs

Protection of human health and the environment is paramount for any source of drinking water, be it reused water or not. To ensure reused water is safe for potable purposes, it is crucial that it meets standards for pathogens and chemicals (federal, state and local), monitoring is robust, comprehensive and continuous, reporting and independent auditing are performed and knowledge gaps and research needs are addressed ${ }^{35}$.

Overall, types of research needed include further evaluations of common drinking water treatment processes and their inactivation and/or removal efficiency, regulated and unregulated contaminants and their expected presence in reused water, microbial, chemical, radiological and emerging contaminants, monitoring of the influents and effluents of water treatment plants and real-time monitoring of water as it passes through the treatment train. This will facilitate rapid responses, immediately identifying any changes in the water quality due to pathogens or chemical pollutants, detect their types and amounts, and decide on the most appropriate response ${ }^{36}$. General risks can also be reduced through wastewater source control, water source diversification and allocation of risks, so that each party can manage the different risks.

A growing area of concern is the presence of commonly used chemicals and emerging contaminants, their mixture even at low doses, and their effect in human health and ecosystems. This is particularly important if they are detected more often in advanced treated water as they can cause acute or chronic diseases. Better regulations, and improved treatment and monitoring have been identified as key to address the above issues and comply with potable water quality parameters ${ }^{37}$. Web-based data analytics and a system for population water reporting are also important as they will enhance data collection, and increase information accessibility.

To further understand risks of emerging contaminants, major research efforts based on toxicological and epidemiological studies have been carried out. At present, however, health and environmental protection relies in the measurement of chemical and microbiological parameters and the application of formal processes of risk assessment. The objective is that identification, quantification and use of risk information informs decision-making on social and environmental impacts and benefits, as well as on financial $\operatorname{costs}^{38}$. Effects on vulnerable groups like infants, elderly, pregnant women, and persons who are already ill, are less understood and thus require additional research.

In direct potable reuse, the absence of an environmental buffer means shorter failure response times, which may affect the ability of plant operators to stop operations if off-specification water is detected. In these cases, supplementary treatment, monitoring, and engineered buffers are expected to provide equivalent protection of public health and response time if water quality specifications are not met ${ }^{39}$.

Table 2 lists benefits and challenges related to potable water reuse. It does not intend to be exhaustive, but to indicate the most relevant issues in both cases. 
Table 2. Benefits and challenges of potable water reuse.

\begin{tabular}{|c|c|}
\hline Benefits & Challenges/concerns \\
\hline $\begin{array}{l}\text { Reliable additional sources of } \\
\text { clean water }\end{array}$ & $\begin{array}{l}\text { Health and environmental } \\
\text { concerns }\end{array}$ \\
\hline $\begin{array}{l}\text { Reduction of water pollution } \\
\text { discharges }\end{array}$ & $\begin{array}{l}\text { Knowledge gaps regarding } \\
\text { mixture of contaminants and } \\
\text { emerging contaminants }\end{array}$ \\
\hline $\begin{array}{l}\text { Preservation of aquatic life and } \\
\text { biodiversity by reducing water } \\
\text { pollution }\end{array}$ & Psychological barriers \\
\hline $\begin{array}{l}\text { Advancement of scientific } \\
\text { knowledge and technology }\end{array}$ & $\begin{array}{l}\text { Technical, managerial and } \\
\text { financial viability of water reuse } \\
\text { schemes }\end{array}$ \\
\hline
\end{tabular}

Potable water reuse schemes are subject to stringent regulations. They follow risk assessment and drinking water safety plans, which include pilot studies, process control considerations, standards, monitoring and auditing of water quality, consideration of stakeholders and public perceptions and risk minimisation, among other factors. Treatment technologies used are advanced and require membrane filtration and ultraviolet disinfection to remove or destroy viruses, bacteria, chemicals, and other constituents of concern as part of the process of converting wastewater into a clean, safe source of municipal drinking water. Reused water is thus cleaner, and safer, than river flows in many cities, especially in the developing world, where improperly treated (or, more commonly, untreated) wastewater is normally discharged.

Potable water reuse and the SDG for water and sanitation Proper treatment of wastewater and safe reuse are prerequisites if the main targets of Goal 6 are to be reached by 2030. Failure to achieve this goal will mean that health and living conditions of billions of people will suffer, as they have suffered until now, or even more, as populations are growing and water resources are scarcer and more polluted.

Wastewater that is treated and safely reused for potable purposes becomes a new source of water that can be supplied to growing populations. Examples mentioned earlier show that there are thousands of people with access to clean water due to potable water reuse. This is water that would not be available otherwise. Potable water reuse has become more relevant during drought periods when populations with access to reused water have not suffered of water rationing, while people elsewhere without this alternative have not had the same opportunity.

Potable water reuse represents a reliable alternative way to produce safe water, improve the quality of water in receiving water bodies, and mitigate water scarcity for all uses, contributing to the SDG on clean water and sanitation. More broadly, to improve overall quality of life. However, such projects alone cannot enable the achievement of SDG 6, and produce all the safe water the world is running short of at present and will need in the future. As argued earlier, water reuse is part of comprehensive water planning and management strategies.

Water scarcity needs to be approached holistically. At present and looking towards the future, when demands for safe water will be more pressing and water resources will be less available than now, all alternatives for water supply must be considered, potable water reuse included.

\section{METHODS}

The study followed a three-method approach. The first was literature review and analysis to understand the range of issues that determine the extent of the contributions of water reuse towards the realisation of clean water and sanitation Sustainable Development Goals in specific, and to the progress of several other non-water related SDGs positively influencing quality of life. Following the review and analysis, the second approach was the discussion of water reuse projects that have been operational for decades and that have rendered numerous benefits to the population in terms of safe water and sanitation, as well as projects that have been halted due to health concerns and insufficient involvement of the public. Finally, the most recent initiatives to strengthen and diversity the water resources available at the national level, e.g., United States, are presented to emphasise the fundamental role of water reuse towards fulfilment of the SDGs on clean water and sanitation.

Received: 28 November 2019; Accepted: 31 March 2020; Published online: 30 April 2020

\section{REFERENCES}

1. United Nations General Assembly (UNGA). Transforming Our World: The 2030 Agenda for Sustainable Development, Seventieth Session Agenda items 15 and 116, https://www.unfpa.org/sites/default/files/resource-pdf/Resolution_A_RES_70_1_EN. pdf (2015).

2. Bain, R. E. S. et al. Accounting for water quality in monitoring access to safe drinking-water as part of the Millennium Development Goals: lessons from five countries. Bull. World Health Organ. 90, 228-235 (2012).

3. United Nations. Water Global Analysis and Assessment of Sanitation and Drinking Water (GLAAS) 2017 Report: Financing Universal Water, Sanitation and Hygiene under the Sustainable Development Goals, https://www.who.int/water_sanitation_health/ monitoring/investments/glaas/en/ (2017).

4. 2030 Water Resources Group and Council of Energy (Environment and Water). Circular Economy Pathways for Municipal Wastewater Management in India: A Practitioner's Guide, https://www.2030wrg.org/wp-content/uploads/2017/01/ Circular-Economy-Pathways-India.pdf (2016).

5. United Nations Environment Programme (UNEP). A Snapshot of the World's Water Quality: Towards a Global Assessment, https://uneplive.unep.org/media/docs/ assessments/unep wwqa report web.pdf (2016).

6. United Nations Children's Fund (UNICEF). Water, Sanitation and Hygiene (WASH): Annual Report 2013, https://www.unicef.org/wash/files/WASH_Annual_Report_Final_7_2_Low_ Res.pdf (2014).

7. Stanaway, J. D. et al. Global, regional, and national comparative risk assessment of 84 behavioural, environmental and occupational, and metabolic risks or clusters of risks for 195 countries and territories, 1990-2017: a systematic analysis for the Global Burden of Disease Study 2017. Lancet 392, 1923-1945 (2018).

8. Hall, N. L., Creamer, S., Anders, W., Slatyer, A. \& Hill, P. S. Water and health interlinkages of the sustainable development goals in remote indigenous australia. npj Clean Water 3, 10 (2020).

9. Damania, R., Desbureaux, S., Rodella, A. S., Russ, J. \& Zaveri, E. Quality Unknown: The Invisible Water Crisis, https://openknowledge.worldbank.org/bitstream/ handle/10986/32245/9781464814594.pdf?sequence=8\&isAllowed=y (2019).

10. Copeland, C. Water Quality Issues in the 114th Congress: An Overview. Report, https://fas.org/sgp/crs/misc/R43867.pdf (2016).

11. U.S. Environmental Protection Agency (USEPA). National Water Quality Inventory: Report to Congress 2004 Reporting Cycle. EPA 841-R-08-001 (USEPA, Washington, D.C., 2009).

12. U.S. Environmental Protection Agency (USEPA). National Lakes Assessment: A Collaborative Survey of the Nation's Lakes. EPA 841-R-09-001 (U.S. Environmental Protection Agency, Office of Water and Office of Research and Development, Washington, D.C., 2009).

13. European Environment Agency (EEA). European Waters-Assessment of Status and Pressures. Report No. 7/2018, https://www.eea.europa.eu/publications/state-of-water (2018).

14. Lazarova, V., Asano, T., Bahri, A. \& Anderson, J. Milestones in Water Reuse (International Water Association, London, 2012).

15. U.S. Environmental Protection Agency (USEPA). 2017 Potable Reuse Compendium. EPA-CDM CRADA 844-15, https://www.epa.gov/sites/production/files/2018-01/ documents/potablereusecompendium_3.pdf (2017).

16. Texas Water Development Board. Final Report Direct Potable Reuse Resource Document, https://www.twdb.texas.gov/publications/reports/contracted_reports/ doc/1248321508_Vol1.pdf (2015).

17. State Water Resources Control Board Resolution No. 2018-0014. Adopting the proposed regulations for surface water augmentation using recycled water https://www.waterboards.ca.gov/board_decisions/adopted_orders/resolutions/ 2018/rs2018_0014_with_regs.pdf (2018).

18. California Water Boards. A Proposed Framework for Regulating Direct Potable Reuse in California, https://www.waterboards.ca.gov/drinking_water/certlic/drinkingwater/ direct_potable_reuse.html (2019). 
19. World Health Organization (WHO). Potable Reuse: Guidance for Producing Safe Drinking-Water, http://apps.who.int/iris/bitstream/handle/10665/258715/ 9789241512770-eng.pdf?sequence=1 (2017).

20. U. S. Environmental Protection Agency (USEPA). National Water Reuse Action Plan. Collaborative Implementation Version I, https://www.epa.gov/sites/production/ files/2020-02/documents/national-water-reuse-action-plan-collaborativeimplementation-version-1.pdf (2020).

21. van Rensburg, P. Overcoming global water reuse barriers: the Windhoek experience. Int. J. Water Resour. D. 32, 622-636 (2016).

22. Tortajada, C. \& van Rensburg, P. Drink more recycled wastewater. Nature 577, 26-28 (2020).

23. Public Utilities Board (PUB). Annual Report 2016/17, https://www.pub.gov.sg/ Documents/annualreport2017.pdf (2017).

24. Tortajada, C., Joshi, Y. \& Biswas, A. K. The Singapore Water Story: Sustainable Development in an Urban City State (Routledge, 2013)

25. European Commission (EU). Commission Staff Working Document. The Fitness Check of EU Freshwater Policy, https://ec.europa.eu/environment/water/blueprint/ pdf/SWD-2012-393.pdf (2012).

26. Janbakhsh, A. Langford Recycling Scheme: United Kingdom-Langford. In 2012 Guidelines for Water Reuse, E114-E115, https://www3.epa.gov/region1/npdes/ merrimackstation/pdfs/ar/AR-1530.pdf (2012).

27. Van Houtte, E. \& Verbauwhede, J. Sustainable groundwater management using reclaimed water: the Torreele/St. Andre case in Flanders, Belgium. J. Water Supply Res. T 61, 473-483 (2012).

28. U.S. Environmental Protection Agency (USEPA). Guidelines for Water Reuse. EPA/ 600/R-12/618, https://www.epa.gov/sites/production/files/2019-08/documents/ 2012-guidelines-water-reuse.pdf (2012).

29. Environment Protection and Heritage Council, the Natural Resource Management Ministerial Council and the Australian Health Minister's Conference. Guidelines for Water Recycling: Managing Health and Environmental Risks (Phase 2). Augmentation of Drinking Water Supplies, https://www.waterquality.gov.au/media/85 (2008).

30. Moscovis, V. Groundwater Replenishment Trial Final Report, https://www. watercorporation.com.au/-/media/files/residential/water-supply/gwrt/gwrt-finalreport.pdf (2013).

31. Hurlimann, A. \& Dolnicar, S. When public opposition defeats alternative water projects-the case of Toowoomba Australia. Water Res. 44, 287-297 (2010).

32. Australian Academy of Technological Sciences and Engineering (ATSE). Drinking Water through Recycling: The Benefits and Costs of Supplying Direct to the Distribution System (ATSE, Melbourne, 2013).

33. Macpherson, L. \& Snyder, S. Downstream-Context, Understanding, Acceptance: Effect of Prior Knowledge of Unplanned Potable Reuse on the Acceptance of Planned Potable Reuse (Water Reuse Research Foundation, Alexandria, VA, 2013).

34. National Academies of Sciences, Engineering, and Medicine. Future Water Priorities for the Nation: Directions for the U.S. Geological Survey Water Mission Area, https://doi.org/10.17226/25134 (2018).

35. National Research Council. Water Reuse: Potential for Expanding the Nation's Water Supply through Reuse of Municipal Wastewater, https://doi.org/10.17226/13303 (2012).
36. National Research Council (NRC). Classifying Drinking Water Contaminants for Regulatory Consideration, https://doi.org/10.17226/10080 (2001).

37. Water Environment Federation (WEF). Water Reuse Roadmap Primer, https://www. wef.org/globalassets/assets-wef/direct-download-library/public/03---resources/ wef_water_reuse_roadmap_primer.pdf (2016).

38. UK Water Industry Research Limited. A Protocol for Developing Water Reuse Criteria with Reference for Drinking Water Supplies, https://www.waterboards.ca.gov/ water_issues/programs/grants_loans/water_recycling/research/02_011.pdf (2005).

39. California Water Resources Control Boards. Recommendations of the Advisory Group on the Feasibility of Developing Uniform Water Criteria for Direct Potable Reuse, https://www.waterboards.ca.gov/drinking_water/certlic/drinkingwater/ rw_dpr_criteria.html (2020).

\section{ACKNOWLEDGEMENTS}

This research was funded by the Institute of Water Policy, Lee Kuan Yew School of Public Policy, National University of Singapore. Grant R-603-000-289-490.

\section{COMPETING INTERESTS}

The author declares no competing interests.

\section{ADDITIONAL INFORMATION}

Correspondence and requests for materials should be addressed to C.T.

Reprints and permission information is available at http://www.nature.com/ reprints

Publisher's note Springer Nature remains neutral with regard to jurisdictional claims in published maps and institutional affiliations.

c)

Open Access This article is licensed under a Creative Commons Attribution 4.0 International License, which permits use, sharing, adaptation, distribution and reproduction in any medium or format, as long as you give appropriate credit to the original author(s) and the source, provide a link to the Creative Commons license, and indicate if changes were made. The images or other third party material in this article are included in the article's Creative Commons license, unless indicated otherwise in a credit line to the material. If material is not included in the article's Creative Commons license and your intended use is not permitted by statutory regulation or exceeds the permitted use, you will need to obtain permission directly from the copyright holder. To view a copy of this license, visit http://creativecommons. org/licenses/by/4.0/.

(c) The Author(s) 2020 